\title{
STRESS DISTRIBUTION IN AN ANISOTROPIC PLANE FIELD WEAKENED BY AN ELLIPTICAL HOLE
}

\author{
Vera Nikolić, Ćemal Dolićanin, Mladen Radojković, Edin Dolićanin
}

Original scientific paper In the paper, the influence of an elliptical hole onto stress condition of an anisotropic (orthotropic) one-axis strengthened panel exposed to static loading is considered. Holes in machine parts represent characteristic sources of stress concentration. The stress distribution around the holes, as the source of stress concentration, is significantly influenced not only by the size of a hole and its material but also by its form and position in relation to the course of action of an outer loading. The aim of this paper is the analysis of the elliptical hole influence, as the source of stress concentration, onto stress distribution. Although in practice the elliptical holes are not as common as the circular ones, it is known that the circular holes represent a special case of the elliptical ones, and all equalities being accomplished within elliptical holes are valid within the circular ones, when half-axes of an elliptical hole have been equalled. In this paper, only the parts from anisotropic (orthotropic) materials are considered, since in practice it has been shown that they can be excellent construction materials. The analytical and numerical methods are used for accomplishment of the stress distribution in a plane isotropic field weakened by holes.

Keywords: anisotropic (orthotropic) materials; elliptical hole; finite elements method; one-axis strengthened panel; stress; stress distribution

Raspodjela naprezanja u ravninskom anizotropnom polju oslabljenom eliptičnim otvorom

Izvorni znanstveni članak

U radu je razmatran utjecaj položaja eliptičnog otvora na stanje naprezanja anizotropne (ortotropne) jednoosno zategnute ploče, izložene statičkom opterećenju. Otvori u strojnim dijelovima predstavljaju karakteristične izvore koncentracije naprezanja. Na raspodjelu naprezanja oko otvora kao izvora koncentracije naprezanja, znatno utječu kako veličina otvora i vrsta materijala, tako i njegov oblik i položaj u odnosu na pravac djelovanja vanjskog opterećenja. Cilj ovog rada je analiza utjecaja eliptičnog otvora, kao izvora koncentracije naprezanja, na raspodjelu naprezanja. Iako se u praksi eliptični otvori rjeđe sreću od kružnih, poznato je da kružni otvori predstavljaju specijalan slučaj eliptičnih i sve jednakosti do kojih se dolazi kod eliptičnih otvora vrijede i za kružne otvore kada se u tim jednakostima poluosi eliptičnog otvora izjednače. U ovom radu razmatrani su samo dijelovi od anizotropnih (ortotropnih) materijala, jer se u praksi pokazalo da isti mogu biti izvanredni konstrukcijski materijali. Za dobivanje rezultata raspodjele naprezanja u ravninskom izotropnom polju oslabljenom otvorima, korištene su analitičke i numeričke metode.

Ključne riječi: anizotropni (ortotropni) materijali; eliptični otvor; jednoosno zategnuta ploča; metoda konačnih elemenata; naprezanje; raspodjela naprezanja

\section{Introduction}

Knowledge on the stress distribution and deformations in zones of geometrical discontinuities of elements in machine constructions is of significant importance in engineering practice. Having in mind a functional fact that a machine construction consists of numerous machine elements that make a functional entity and each one of these elements can have at least one zone where there is a discontinuity, then the issue included in the title of this paper becomes more than the current interest. Thereby, everything can be reconsidered in a real three-dimensional space, or with certain simplifications, the current issue can be reduced to two-dimensional. Therefore, in Elasticity Theory, there are two cases and they are the plane one (flat condition) of the stress and the plane (flat) deformation, depending on what effects happened under the influence of the outer load.

The primary and most significant task in designing complex machine parts, i.e. structural elements, is a regular reconsideration of all parameters influencing the stress condition. This approach means defining critical zones within constructions and their structural elements.

During an intensive scientific development, there have been created numerous theoretical and practical models for analysis, synthesis and examination of constructions. Based on the created physical form of a machine construction, simpler models are crated, and then, a mathematical model is chosen for calculation and analysis of the construction. The analysis is performed by a chosen theoretical (analytical), numeric and experimental method, "step by step" the construction has been improved until the desired results are accomplished. Practically, by the analysis, the data have been collected that allow correction of constructional solutions, i.e. evolution of the existing ones or improvement of newly developed constructions. Besides this, by the analysis methods, the data have been collected as well as the knowledge to develop future machine constructions. Depending on the speed of the analysis performance, the construction features can be early identified, i.e. several constructional variants can be developed and, thus, the most appropriate solution chosen.

Today a significant number of constructions have been developed from anisotropic materials, in the aim of securing minimal mass and satisfying firmness demands. Anisotropy is a feature of some bodies to show different physical and mechanical features in different directions, e.g. elasticity, stress, deformation and others. Numerous construction materials have anisotropic characteristics (policrystals, crystals, wooden constructions and a line of others), or a construction is composed of layers with orthotropic characteristics (composite materials). Anisotropic materials, besides other good characteristics, are appropriate from the aspect of their corrosion resistance, abrasive resistance and others.

In this paper, special attention shall be devoted to studying stress distribution around an elliptical hole and differently placed ones, in relation to the axis of machine elements from anisotropic materials. 
To solve differential equations giving the relation among stress condition, deformation condition and outer loading, additional conditions have been included on monosemy of component movements and stress. The stress function, in that case, shall be monosemic if the main vector and the main loading moment that affect the contour of each hole, are equal to zero. The methods of structural analysis of machine constructions, being used for solution of established equations, i.e. determination of needed parameters, can be classified into two groups: analytical and numerical.

Analytical methods include determining mathematical functions by defining a solution in a closed form. They are based on Elasticity Theory and material resistance [1 $\div 6$ ]. With firm elastic bodies, the relations among outer loading, inner forces and deformations have been studied. For solving these and similar issues, a method of complex variables is applied. The primary idea of this method is that stress function is expressed by analytical functions of a complex variable-analytical complex functions. When this has been done for a rectangular Cartesian or cylindrical-polar coordination system, the vector's movement components have been defined with a certain stress function of a complex variable $[1,7,8]$. These expressions, in this case, are derived with satisfying of bordering or contour conditions including outer surface forces. Analytical functions of a complex variable are presented in a form of degree lines with complex constant coefficients. For solution of concrete tasks, lines with a finite number of members are used, so as to ease the solution $[1,7,8]$.

The primary characteristic of numeric methods consists in fundamental equations of the Elasticity Theory, including bordering conditions, solved in an approximate numeric way $[15 \div 17]$. In mathematical sense, instead of differential equations (ordinary, partial or integral ones), defining a balance condition of the entire model, by applying FEM, a system of ordinary algebra equations is gained. In this paper, the finite elements method assuming discretisation in a physical model is used. Finite element method (FEM) is applied, already used efficiently in similar issues, [14 $\div 16,18 \div$ 25]. For generating a finite element net and accomplishment of results of the stress distribution, a programme package - NASTRAN [28] has been used.

The method of solving the issue of stress distribution in a thin isotropic plate weakened by any type of holes by applying conformal mapping, was developed by N. I. Mushelishvili [2]. Mushelishvili's method was adapted by G. N. Savin [7] for anisotropic materials. A great contribution in this field was given by S. G. Lehnicki [1].

The authors N. F. Guryev [9], M. P. Šermetjev [10] and S. Timoshenko [3], applied one of the basic numerical methods - Finite Difference Method, based on replacing differential equations with corresponding difference equations and others. Mushelishvili N. I. [2] showed that the solution of such issues can be accomplished through analytic functions of complex variables and mapping functions, being also a complex mathematical task.

There are several worldwide renowned authors who studied the stress state around elliptical holes in multilayer orthotropic plates as, for example, the authors in the paper [11] "on computation of stresses around holes in anisotropic plates". The author of the paper [12] studied the firmness of composite laminates used within airplane constructions. In the papers [13, 14], the procedure of stress calculation in the points along contour of an elliptical hole of a stress loading is shown. The author of the paper [15] presented basic unified methods of finite elements, in incremental formulation, used in the analysis of tension and deformations in constructions where plastic deformations appeared.

The aim of this paper is reconsideration of the influence of hole forms on stress distribution in the contour and around of an elliptical hole placed under a certain angle in relation to the main directions of elasticity in anisotropy material, by using analytical and numerical methods.

\section{Analytical method and analytical results view}

In this paper, the results in the area of anisotropic influence (orthotropic) of materials onto stress distribution around holes will be presented $[1,3,7,8]$, i.e. elastic tension of an orthotropic plate with elastic hole, whose contour is far enough from a plate contour will be discussed in details [3]. Plate tension is performed with surface forces in one direction, where angle attack force closes a certain angle with the main holes' axis. It is assumed that one of the surface elastic symmetry is parallel in the middle plane of a plate, that directions of the main axis of ellipsis $x$ and $y$ do not overlap with the main elasticity directions $\xi$ and $\eta$, that in the hole outline, there are no outer forces, and the contour is not connected in any way. The reconsidered plate is considered an infinite one, and loading affects into infinity.

Starting from the expressions in [1] and [20], in further text, a solution will be shown of the task presented in Fig. 1, where: $2 a, 2 b-$ are the main ellipse axis; $c=a / b$; $p$ - surface forces; $\varphi$ - angle between loading lines and the main ellipse axis $2 a ; \psi$ - angle between direction of the main ellipse axis $2 a$ and the main elasticity axis $\xi ; E_{1}, E_{2}$ - elasticity modules for the main directions $\xi$ and $\eta ; v_{1}, v_{2}$ - Poisson's ratio; $G$ - shear modulus for a plane $\xi, \eta ; a_{i j}$ deformation coefficient from the equation of the General Hook's Law related to the $x$ and $y$ axes; and also material parameters:

$m=\frac{E_{1}}{G}-2 v_{1}, \quad k=\sqrt{\frac{E_{1}}{E_{2}}}, n=\sqrt{2 k+m}$.

Since $m$ and $n$ are mutually dependent parameters, in formulas for calculation of stress in orthotropic plate, shall figurate only two of three stated parameters (1). Let the ones be parameters $n$ and $k$ that can be named material parameters of general plane stress condition of anisotropy, more precisely, of orthotropic plate. Material parameters of a plane deformation of orthotropic middle can also be presented in the following form: 


$$
m=\frac{2 \beta_{12}+\beta_{66}}{\beta_{11}}, k=\sqrt{\frac{\beta_{22}}{\beta_{11}}}, n=\sqrt{2 k+m},
$$

where $\beta_{11}, \beta_{12}, \beta_{22}, \beta_{66}$ are deformation coefficients by Lehnicki [1]. But in this case, to determine the material parameters, Eq. (1) is used.

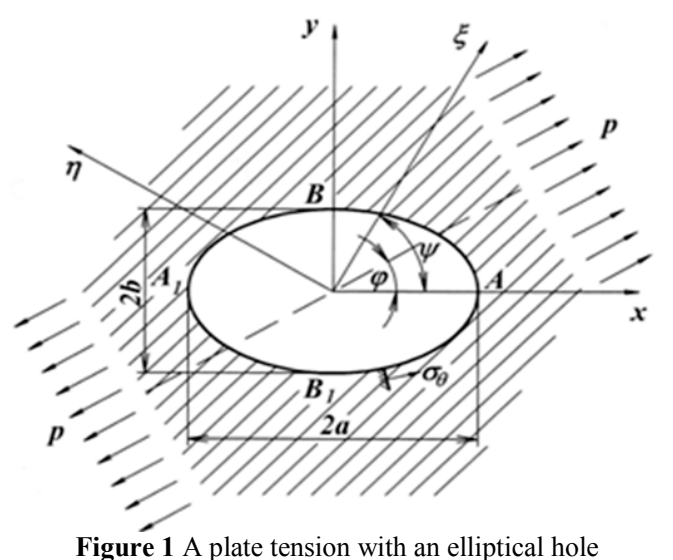

In the case of isotropic middle $k=1, n=2$, and in the case of orthotropic middle $k \neq 1, n \neq 2$, and it can be concluded that these parameters are characterized by deviation of certain middles from anisotropic, i.e. they serve as an anisotropy measure.

In the aim of simplifying certain expressions, the following marks will be used in the text, according to [1] and [20]:

$K=0,5 n(1-k) \sin 2 \psi$

$L=0,5 n[1+k+(1-k) \cos 2 \psi]$

$M=0,5\left\lfloor 1-k^{2}+\left(1+k^{2}-m\right) \cos 2 \psi\right\rfloor \sin 2 \psi$

$N=0,25\left(1+k^{2}-m\right) \sin ^{2} 2 \psi-k$

$P=0,125\left[3+m+3 k^{2}+4\left(1-k^{2}\right) \cos 2 \psi+\right.$

$\left.+\left(1+k^{2}-m\right) \cos 4 \psi\right]$.

According to [1] and [20], the equations of General Hook's Law that actually represent a connection between stress components and deformations can write the main axis $\xi$ and $\eta$ in the form of:

$$
\begin{aligned}
& \varepsilon_{\xi}=\frac{1}{E_{1}} \sigma_{\xi}-\frac{v_{2}}{E_{2}} \sigma_{\eta} \\
& \varepsilon_{\eta}=-\frac{v_{1}}{E_{1}} \sigma_{\xi}+\frac{1}{E_{2}} \sigma_{\eta} \\
& \gamma_{\xi \eta}=\frac{1}{G} \tau_{\xi \eta} .
\end{aligned}
$$

And for axis $x$ and $y$ :

$$
\begin{aligned}
& \varepsilon_{x}=a_{11} \sigma_{x}+a_{12} \sigma_{y}+a_{16} \tau_{x y} \\
& \varepsilon_{y}=a_{12} \sigma_{x}+a_{22} \sigma_{y}+a_{26} \tau_{x y} \\
& \gamma_{x y}=a_{16} \sigma_{x}+a_{26} \sigma_{y}+a_{66} \tau_{x y} .
\end{aligned}
$$

Coefficients $a_{i j}$ are expressed with elastic constants,
[1] and [20], in the following way:

$$
\begin{aligned}
& a_{11}=\frac{P}{E_{1}} \\
& a_{22}=\frac{1}{E_{1}}\left[P+\left(k^{2}-1\right) \cos 2 \psi\right] \\
& a_{12}=\frac{1}{E_{1}}\left[-v_{1}+0,25\left(1+k^{2}-m\right) \sin ^{2} 2 \psi\right] \\
& a_{66}=\frac{1}{E_{1}}\left[\frac{E_{1}}{G}+\left(1+k^{2}-m\right) \sin ^{2} 2 \psi\right] \\
& a_{16}=\frac{1}{2 E_{1}}\left[1-k^{2}+\left(1+k^{2}-m\right) \cos 2 \psi\right] \sin 2 \psi \\
& a_{26}=\frac{1}{2 E_{1}}\left[1-k^{2}-\left(1+k^{2}-m\right) \cos 2 \psi\right] \sin 2 \psi
\end{aligned}
$$

The equation contours of an elliptical hole, in a parameter form, have the form of:

$$
x=a \cos \theta, y=b \sin \theta,(a \geq b)
$$

Also, in the aim of simplifying, the marks for functions dependant on the parameter $\theta$ can be introduced:

$l^{2}=c^{2} \sin ^{2} \theta+\cos ^{2} \theta$

$S=E_{1}\left[a_{11} c^{4} \sin ^{4} \theta-2 a_{16} c^{3} \sin ^{3} \theta \cos \theta+\right.$

$+\left(2 a_{12}+a_{66}\right) c^{2} \sin ^{2} \theta \cos ^{2} \theta-$

$\left.-2 a_{26} c \sin \theta \cos ^{3} \theta+a_{22} \cos ^{4} \theta\right]$

In engineering practice, the most significant are the values of the stress in the hole contour $\sigma_{\theta}$, as it has been proved, and they have the highest values. Calculation formula of stress in the very contour of an elliptical hole can be expressed in the form of:

$\sigma_{\theta}=\frac{p l^{2}}{S}\left(\left\{N c \sin ^{2} \varphi+(K+M c) \sin \varphi \cos \varphi+\right.\right.$

$\left.+(L+P c) \cos ^{2} \varphi\right\} c \sin ^{2} \theta-$

$\left\{[M N+K(L+P c)] c \sin ^{2} \varphi+\right.$

$+[M(K+M c)+L c(L+P c)-L N] \sin \varphi \cos \varphi+$

$\left.+(K+M c) P \cos ^{2} \varphi\right\} \frac{\sin \theta \cos \theta}{P}+\{[K(K+M c)+$

$+N(N-L c)] \sin ^{2} \varphi+[M N+K(L+P c)] \sin \varphi \cos \varphi+$

$\left.\left.+P N \cos ^{2} \varphi\right\} \frac{\cos ^{2} \theta}{P}\right)$

When $\varphi$ and $\psi$ have the values 0 or $\pi / 2$, a calculation stress expression has been gained for four basic cases, when a hole is placed so that directions of big and small axis of an elliptical hole overlap with the main elasticity axis, and the tension is in direction of either big or small hole axis. In a special case, during tension in a small axis direction $(\varphi=\pi / 2)$, a calculation stress expression in the contour gets the form of: 


$$
\sigma_{\theta}=\frac{p l^{2}}{S} k\left[-c^{2} \sin ^{2} \theta+(k+c n) \cos ^{2} \theta\right],(\psi=0)
$$

or

$$
\sigma_{\theta}=\frac{p l^{2}}{S}\left[-k c^{2} \sin ^{2} \theta+(1+c n) \cos ^{2} \theta\right],(\psi=\pi / 2) .
$$

It is natural to expect that when $c>1$, the highest stress values are in points of a big axis of an elliptical hole. The same one is possible to be accomplished according to the following formula:

$$
\left(\sigma_{\theta}\right)_{\theta=0}=p\left(1+\frac{c n}{k}\right), \quad(\psi=0)
$$

or

$$
\left(\sigma_{\theta}\right)_{\theta=0}=p(1+c n), \quad(\psi=\pi / 2) .
$$

Certainly, it should be emphasized that this claim is not valid for any values of the parameters $k$ and $n$, and for some values of the parameters $k$ and $n$, the highest stress values are in points of a small axis, not a big one. In that case, tension stresses will be obtained.

It should be noticed that stress concentration around a hole has an enormous influence onto the shear modulus $G$ that is featured in the expression for the parameter $n$.

In further text, the results will be illustrated accomplished for a birch veneer plate. In Tab. 1, the highest stress tension values are given $\sigma_{\max }$ in the contour of an orthotropic veneer plate. The relation of half-axis of a hole is $c=a / b=2$. Five cases of stress orientation compared to the big axis of the elliptical hole have been reconsidered and eight cases of orientations of the main elasticity directions.

Table 1 The values of stress tension $\sigma_{\max }$

\begin{tabular}{|c|c|c|c|c|c|c|c|c|c|}
\hline \multirow{2}{*}{$\varphi^{\circ}$} & \multicolumn{10}{|c|}{$\psi^{\circ}$} \\
\cline { 2 - 11 } & 0 & 30 & 45 & 60 & 90 & 120 & 135 & 150 & 180 \\
\hline 0 & 3,23 & 2,76 & 2,67 & 2,21 & 2,57 & 2,21 & 2,67 & 2,76 & 3,23 \\
\hline 30 & 3,10 & 4,92 & 4,64 & 4,96 & 2,55 & 3,80 & 4,00 & 3,76 & 3,10 \\
\hline 45 & 3,85 & 5,55 & 5,84 & 6,93 & 6,19 & 4,28 & 4,98 & 5,18 & 3,85 \\
\hline 60 & 5,58 & 5,47 & 6,52 & 8,20 & 7,55 & 4,24 & 5,33 & 6,14 & 5,58 \\
\hline 90 & 7,20 & 5,77 & 5,52 & 7,72 & 9,91 & 7,72 & 5,52 & 5,77 & 7,20 \\
\hline
\end{tabular}

By analysing the accomplished results, certain conclusions can be derived for the veneer plate, and they can be valid for other anisotropy materials, where $k>1$ and $n>2$. With the elliptical hole, it can be seen that the highest values of these stresses are accomplished in a case when a hole is made so as to overlap the direction of the small axis with direction where elasticity module is the highest, and tension in direction of the small hole axis.

\section{The basic equation view in FEM and numerical results}

In this paper, for modelling of the continuum in a plane condition of stress and strain, where the plates also belong, 2D finite elements have been used [16, 18, 25], Fig. 2. The principle of minimum potential energy, a displacement method, as a form of the finite element method, has been used. Special mathematical models have been established for simulation of real loads and boundary conditions in the parts of metal structures with geometrical discontinuity.

A detailed view of the used finite element is given in $[16,18,25]$, and some of the most significant relations will be presented here.

The finite element, approximating a displacement field, must have nodes lying in the $x y$ plane with displacements having components in the direction of the $x$ and $y$ axis. Thus, the displacement field of points can be defined by a vector field, [16, 18, 25], in the following way:

$$
\{s\}=\mathbf{s}=\left\{\begin{array}{l}
u \\
v
\end{array}\right\}=[h] \mathbf{q}_{K}=[h]\{q\}_{(K)} .
$$

Interpolation of geometry can be written in the following form:

$x=\left\{\begin{array}{l}x_{1} \\ x_{2}\end{array}\right\}=\left\{\frac{x}{y}\right\}=H X$,

where $H$ is an interpolation matrix.

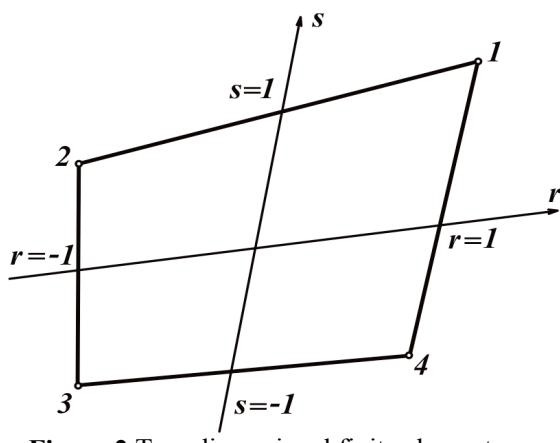

Figure 2 Two-dimensional finite element

The general form of constitutive equations, i.e. the relation between stress components and strain components for elastic material representing a generalization of the known Hooke's Law, can be shown as

$\{\sigma\}=[D]\{\boldsymbol{\varepsilon}\}$ or $\boldsymbol{\sigma}=\boldsymbol{D} \boldsymbol{\varepsilon}$,

where $\boldsymbol{D}$ is the matrix of elastic constants or constitutive matrix being in [26].

The basic equation of the finite element giving the relation between the nodal displacements and nodal forces for the finite element:

$\{\boldsymbol{F}\}=\left[\boldsymbol{K}^{\mathrm{e}}\right]\{\mathbf{S}\}$.

The matrix $\left[\boldsymbol{K}^{\mathrm{e}}\right]$ is stiffness matrix of the finite element, depending on the physical properties of materials, the coordinates of elements and interpolation functions.

A construction equation is obtained by joining e Eq. (18) into a group equation as the form: 


$$
\{\mathrm{F}\}=[\mathrm{K}]\{\mathbf{S}\},
$$

where $\{\mathbf{F}\}$ is matrix of the columns whose elements are components of the generalized nodal forces and $\{\mathbf{S}\}$ is matrix of the columns whose elements are components of the nodal displacement vectors.

In this research to generate networks of finite elements and to obtain results of distribution of stress, the "NASTRAN" program package was used.

In further text, the results of stress distribution are shown $\sigma_{\max }$ in the plane anisotropic field weakened by the elliptical hole. The accomplished results are related to element type plates, whose dimensions are $120 \times 120 \times 1$ $\mathrm{m}$. The same ones are weakened by elliptical holes. The holes' dimensions are given for each example separately. The loading is uni-axis (in the direction of the $x$ or $y$ axis) and it is $p=1 \mathrm{~N} / \mathrm{m}^{2}$. The material the plates were made of is birch veneer where the values of elasticity module in the main axis directions are $E_{\max }=1,2 \times 10^{10} \mathrm{~N} / \mathrm{m}^{2}$ i $E_{\text {min }}$ $=0,6 \times 10^{10} \mathrm{~N} / \mathrm{m}^{2}$, shear module $G=0,07 \times 10^{10} \mathrm{~N} / \mathrm{m}^{2}$, and Poisson's coefficients in the stated directions are $v_{\max }$ $=0,071$ and $v_{\min }=0,036$. The researches were performed so as, in examples, the main directions of material elasticity overlapped with the directions of coordinate axis $x$ and $y$, and loading was effected along one of coordinate axes.

In the following examples, uni-axis tensioned orthotropic plate weakened by an elliptical hole is reconsidered. Tensioning is performed in the direction of the $x$, i.e. $y$ axis, by surface forces $p=1 \mathrm{~N} / \mathrm{m}^{2}$. The axes $x$ and $y$ overlap with the main material elasticity directions. The lengths of elliptical hole axis are $a=2 \mathrm{~m}$ and $b=1$ m.

In Figs. 3a, 3b, 3c and 3d, only a detail of stress distribution $\sigma_{\max }$ around a hole is given, since the view of the entire stress distribution would be unclear (immense), and the highest stress values appear near a hole.

Fig. 3a shows stress distribution $\sigma_{\max }$ during tensioning in the direction of the $x$ axis, when the $\mathrm{x}$-axis coincides with the direction corresponding to the maximum value of the modulus of elasticity, $E_{\mathrm{x}}=E_{\max }$ and the $y$ axis coincides with the direction that corresponds to the modulus of elasticity minimum value, $E_{\mathrm{y}}=E_{\min }$. The highest accomplished value of the maximal tension stress is $\sigma_{\max }=3,191 \mathrm{~N} / \mathrm{m}^{2}$.

Similarly, when the $x$-axis coincides with the direction that corresponds to the minimum value of the modulus of elasticity $E_{x}=E_{\min }$, then is $E_{\mathrm{y}}=E_{\max }$ and the highest accomplished value of the maximal tension stress is $\sigma_{\max }=2,562 \mathrm{~N} / \mathrm{m}^{2}$ (Fig. $3 b$ ).

In Fig. 3 c, stress distribution is shown $\sigma_{\max }$, during tensioning in the direction of the $y$ axis, when the same coincides with the direction of minimum values of modulus of elasticity, $E_{\mathrm{y}}=E_{\min }$ and the $x$ axis coincides with the direction that corresponds to the maximum value of the modulus of elasticity $E_{\mathrm{x}}=E_{\max }$. The highest accomplished value of the maximal tension stress is $\sigma_{\max }$ $=7,586 \mathrm{~N} / \mathrm{m}^{2}$.

Similarly, when the $x$ axis coincides with the direction that corresponds to the maximum value of the modulus of elasticity $E_{y}=E_{\max }$, then is $E_{\mathrm{x}}=E_{\min }$ and the highest accomplished value of the maximal tension stress is $\sigma_{\max }=9,536 \mathrm{~N} / \mathrm{m}^{2}$ (Fig. $3 \mathrm{~d}$ ).

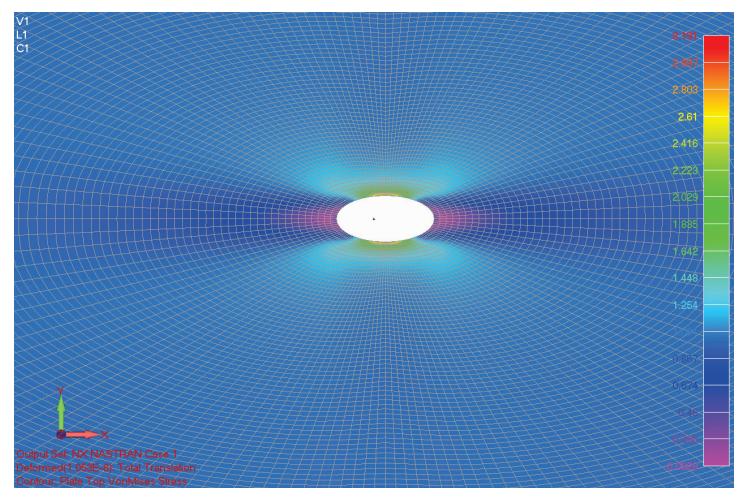

Figure 3a Stress distribution $\sigma_{\max }$ during the plate tensioning weakened by an elliptical hole in the direction of the $x$ axis

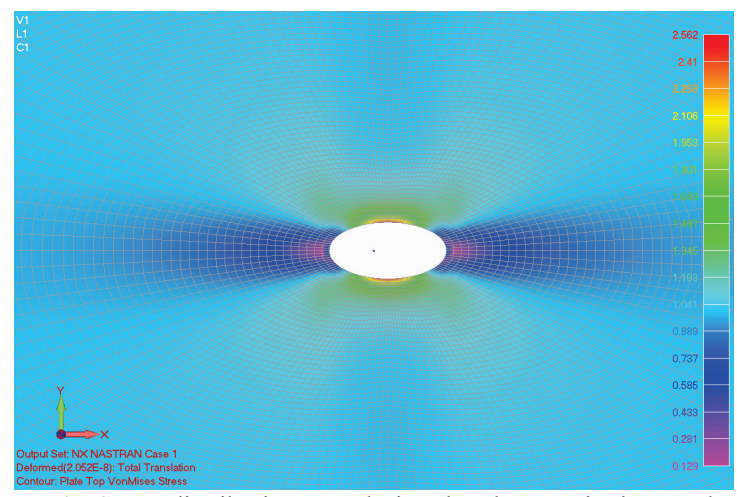

Figure 3b Stress distribution $\sigma_{\max }$ during the plate tensioning weakened by an elliptical hole in the direction of the $x$ axis

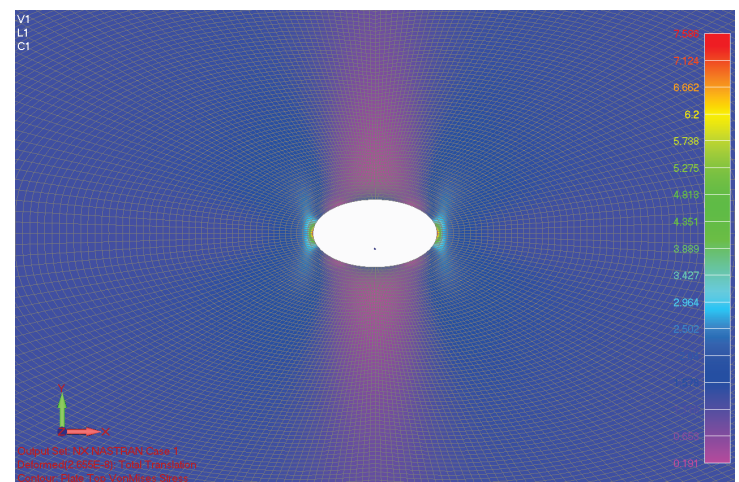

Figure 3c Stress distribution $\sigma_{\max }$ during the plate tensioning weakened by an elliptical hole in the direction of the $y$ axis, when the $y$ axis overlaps

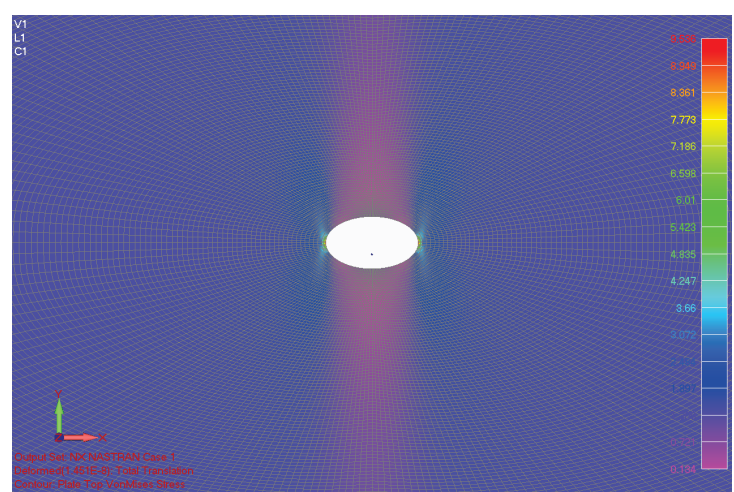

Figure 3d Stress distribution $\sigma_{\max }$ during the plate tensioning weakened by an elliptical hole in the direction of the $y$ axis, when the $y$ axis overlaps 


\section{Comparison of analytical and numerical results}

In the aim of verifying accomplished results in analytical and numerical way, the values of the maximal tension stress were compared $\sigma_{\max }$, accomplished for uniaxis tensioned orthotropic plate weakened by an elliptical hole, placed in a way so that its longer axis is parallel with the $x$ axis, and a shorter one is parallel with the $\mathrm{y}$ axis.

Tab. 2 presents the values of the maximal tension stress verified in numerical and analytical way.

Based on the accomplished results for the strengthened orthotropic plate along the $x$ and the y axis, respectively, it can be seen that the highest values of stress $\sigma_{\max }$ are gained during strengthening in the direction normal to the big axis of the elliptical hole, and when the shorter axis overlaps with the directions of attacking lines of strengthening forces and direction being appropriate to the highest values of elasticity module, care must be taken during making of elliptical holes in the parts of orthotropic materials.

Table 2 Stress values $\sigma_{\max }$

\begin{tabular}{|c|c|c|}
\hline \multicolumn{4}{|c|}{ Table 2 Stress values $\sigma_{\max }$} \\
\hline Method & $E$ & $\sigma_{\max }, \mathrm{N} / \mathrm{mm}^{2}$ \\
\hline \multicolumn{2}{|c|}{ Tensioning in the direction of $x$ axis } \\
\hline FEM & $E_{\mathrm{x}}=E_{\max }$ & 3,191 \\
& $E_{\mathrm{y}}=E_{\min }$ & 3,230 \\
\hline ANAL & $E_{\mathrm{x}}=E_{\min }$ & 2,562 \\
\cline { 1 - 1 } FEM & $E_{\mathrm{y}}=E_{\max }$ & 2,570 \\
\hline ANAL & $E_{\mathrm{x}}=E_{\max }$ & 7,586 \\
Tensioning in the direction of $y$ axis \\
\cline { 1 - 1 } FEM & $E_{\mathrm{y}}=E_{\min }$ & 7,200 \\
\hline ANAL & $E_{\mathrm{x}}=E_{\min }$ & 9,536 \\
\cline { 1 - 1 } FEM & $E_{\mathrm{y}}=E_{\max }$ & 9,910 \\
\hline ANAL &
\end{tabular}

Based on the accomplished data, it can be noticed that there is a huge coincidence of the results, and this emphasises the regularity of developed procedures. Further on, there is a conclusion that the values accomplished in numerical way are reliable, and in further research, they can reduce very complex analytical and very expensive experimental researches.

\section{Conclusions}

In this paper, for determining the Figure of stress condition within structural elements of machine constructions with geometric discontinuities, analytical and numeric methods have been used. Therefore, it has been shown in the paper how to gain a solution in analytical way, and the accomplished results, while using this method, were used for verification of results accomplished in numerical way, finite elements method (FEM). Based on the accomplished results in this paper, a conclusion can be made that by applying the finite elements method, the issues of stress deformation conditions of thin plates with different forms of holes can be efficiently solved, and the developed method and the application of finite elements method makes significantly easier finding solutions for stresses, deformations and other, and this gives a significant advantage to this method compared to classical analytical methods.
This paper has been a try to accomplish certain results and conclusions that can serve usefully to all researchers or users in this area.

The accomplished results can be used in practice and scientific research since their credibility has already been confirmed.

Of course, in this area, there are numerous researches ahead that should be directed to solving of these and more complex examples from the aspect of geometry and anisotropy of materials, temperature stresses, elastoplastic, dynamic and other issues.

In future research, the authors will pay attention to the study of the cracking at the edges of the hole, as in $[26,27]$.

\section{Acknowledgement}

Parts of this research were supported by the Ministry of Sciences, Technologies and Development of the Republic Serbia through Mathematical Institute SANU Belgrade and Faculty of Mechanical Engineering University of Niš Grants No. ON144002 Dynamics of hybrid systems with complex structures. Mechanics of Materials.

\section{References}

[1] Лехницкий, С. Г. Теория упругости анизотропного тела, Гостехиздат, М.-Л., 1977.

[2] Мусхелишвили, Н. И. Некоторые основные задачи математической теории упругости, Издательство АН CCCP, 1964.

[3] Тимошенко, С.; Гудиер, Ј. Н.; Теорија еластичности, 1962 (превод).

[4] Rašković, D. The Theory of Elasticity, Science book, Belgrade, 1985.

[5] Kojić, M. Theory of elasticity (in Serbian), Faculty of Mechanical Engineering, Kragujevac.

[6] Jones, R. M. Mechanics of composite materials. Philadelphia: Taylor \& Francis, 1975.

[7] Савин, Г. Н. Распределение напряжений около отверстий, Издательство "Наукова думка", Кијев, 1968.

[8] Михлин, С. Г. Плоская деформация в анизотропной среде, Издательство АН СССР, М.-Л., 1976.

[9] Gurjev, N. F. O naprjaženom sostojaniji plastinki oslabljenoj krivoljinjejnim otverstijem, Inž. žurn. 1974.

[10] Šermetjev, M. P. Plastinki s podkrepljenim krajem, Izd-vo Ljvovsk, 1960.

[11] Tung, T. K. On computation of stresses around holes in anisotropic plates. // Journal of Composite Materials. 21, (1987), pp. 100-104. DOl; 10.1177/002199838702100201

[12] Tan, S. C. Notched strength prediction and design of laminated composites under in - plane loadings. Journal of Composite Materials. 21, (1987), pp. 750-780. DOl: 10.1177/002199838702100804

[13] Veličković, V. Koncentracija napona u tačkama oko eliptičnog otvora ravanski napregnute višeslojne ortotropne ploče. // Scientific Technical Review. 52, 4(2002), pp. 3743.

[14] Veličković, V. Contribution to analysis of stress state at points around elliptic opening in an in-plane stressed orthotropic plate. // Scientific Technical Review. LVII, 1(2007), pp. 66-72. 
[15] Pustaić, D. Numerical Modelling of a Plate with an Elliptical Hole in Plastic Range, Hrvatska znanstvena bibliografija, Radovi Fakulteta strojarstva i brodogradnje Sveučilišta u Zagrebu (1331-2758) 23 (1999); 5-14 Castrocaro Terme, Italy, pp. 159-160.

[16] Bathe, K. J.; Wilson, E. L. Numerical Methods in Finite Element Analysis, Prentice-Hill, INC Englewood Cliffs, New Jersey, 1976.

[17] Desai, S. C. H.; Abel, F. J. Introduction to the Finite Element Method for Engineering Analysis, Van Nostrand Reinhold Company, New York, 1972.

[18] Kojić, M.; Slavković, R.; Zivković, M. i dr. Metod konačnih elemenata 1, Mašinski fakultet, Kragujevac, 1998.

[19] Dolićanin, Ć.; Nikolić, V.; Radojković, M. Development of the dynamic and mathematical models for the analysis of discrete systems // Proceedings of the $2^{\text {nd }}$ International Congress of Serbian Society of Mechanics (IConSSM 2009), Palić (Subotica), Serbia,1-5.06.2009.

[20] Радојковић, M. Naponsko deformaciono stanje u zonama geometrijskih diskontinuiteta elemenata mašinskih konstrukcija, doktorska disertacija, Kragujevac, 2008.

[21] Nikolić, V.; Dolićanin, Ć.; Radojković, M. Application of Numerical methods in Solving a Phenomenon of the Theory of thin Plates. // Scientific Technical Review. 60, 1(2010), M51.

[22] Tamizharasan, T.; Senthil Kumar, N. Optimization of Cutting Insert Geometry Using DEFORM-3D: Numerical Simulation and Experimental Validation. // International Journal of Simulation Modelling. 11, 2(2012), pp. 65-76. DOI: 10.2507/IJSIMM11(2)1.200

[23] Volk, M.; Nardin, B.; Dolsak, B. Determining the optimal area-dependent blank holder forces in deep drawing using the response surface method. // Advances in Production Engineering \& Management. 9, 2(2014), pp. 71-82. DOl: 10.14743/apem2014.2.177

[24] Deng, W. J.; Xie, C. Z.; Li, Q.; Lin, P. Finite element modelling and simulation of chip breaking with grooved tool. // International Journal of Simulation Modelling. 12, 4(2013), pp. 264-275. DOI: 10.2507/IJSIMM12(4)5.250

[25] Nikolić, V.; Dolićanin, Ć.; Radojković, M. Application of finite element analysis of thin steel plate with holes. // Tehnički vjesnik-Technical Gazette. 18, 1(2011), pp. 57-82.

[26] Maksimović, K.; Nikolić, V.; Maksimović, S. Modeling of the surface cracks and fatigue life estimation // Proceedings of the ECF 16 (2006), Mini symposium integrity of dynamical systems, Alexandroupolis, July 3.-7, (2006), pp. 113-116.

[27] Maksimovic, S.; Posavljak, S.; Maksimovic, K.; Nikolic, $\mathrm{V}$.; Djurkovic, V. Total fatigue life estimation of notched structural components using low cycle fatigue properties. // Journal STRAIN, ISSN 0039-2103, (2010).

[28] MSC/"NASTRAN, program package

\section{Autors' addresess}

Dr Vera Nikolic, full professor

State University of Novi Pazar

Vuka Karadžića bb, 36300 Novi Pazar, Serbia

E-mail: veranikolic1@gmail.com

\section{Dr Ćemal Dolićanin, full professor}

(Corresponding author)

State University of Novi Pazar

Vuka Karadžića bb, 36300 Novi Pazar, Serbia

E-mail: cemaldolicanin@yahoo.com

Dr Mladen Radojković, Professor of Professional Studies

High Technical School of Professional Studies Zvecan

Nušićeva 6, 38227 Zvečan, Serbia

E-mail: mladen_radojkoviczp@yahoo.com
Dr Edin Dolićanin, assistant professor

State University of Novi Pazar

Vuka Karadžića bb, 36300 Novi Pazar, Serbia

E-mail: edin.dolicanin@yahoo.com 